\title{
Electoral Reforms in India: Needs, Issues and Challenges
}

\author{
Dr. Vikash Kumar \\ Research Scholar, Centre for West Asian Studies, School of International Studies \\ Jawaharlal Nehru University, New Delhi
}

\begin{abstract}
India's freedom signalled the end of European imperialism and new start of rule of people in India through democratic principles, values and norms. Democracy, equality and fundamental rights became the core value of India's constitution. Indian constitution accepted parliamentary democracy because freedom struggle has given experience of democratic value to Indians. Democracy believes in the people and their political rights. Parliamentary democracy has taken steps to protect the democratic principles, trust and values from structural flaws. In this regard, electoral process and electoral politics is the life and soul for consolidation of parliamentary democratic system in India. The free and fair elections are fundamental basis for success of democracy. Political stability can secure through people's political participation. Electoral system is necessary and important instrument to make parliamentary democracy work. Under the constitutional values and guidelines of election commission free and fair elections are held at regular intervals in India. To make them from free of flaws it is essential to reform the electoral system from time to time. This paper evaluates need, issues and challenges for electoral reforms in India.
\end{abstract}

Keywords: Parliamentary Democracy, Democratic principles, Political Participation, Election, Political Stability, Electoral Reform

DOI: $10.7176 / \mathrm{PPAR} / 10-9-03$

Publication date:September $30^{\text {th }} 2020$

\section{Introduction}

Indian constitution has accepted parliamentary democracy and has given right to vote on the principle of universal adult franchise. Elections are important features of parliamentary democracy which is held at regular intervals from time to time. People's faith and trust is essential for success of parliamentary democracy. India is the world's largest democracy with 900 million voters. Therefore, free and fair elections are essential for the political stability and healthy democracy. Elections are indispensable to any political system which claims itself democratic (Desai 2016, p. 211). In India, the state governments and union government draws its authority from the Indian citizens.

It is the Indian citizens who have the sovereign power to elect their representatives, form and change their government. The elected governments are responsible to the Indian citizens who have elected them. But the Indian citizens who elect the representatives for formation of governments have no right to recall or dismiss the representatives on the ground that they are unsatisfactory for their post. In this situation, the Indian citizens can reject the representatives through elections which is held at regular intervals. Elections are practical practical form of democracy. The consent of the Indian citizens is expressed through the the elections in parliamentary form of democracy. In other words, the governments get legitimacy through electoral process.

Indian constitution has adopted 'First Past the Post' (FPTP) electoral system. The 'First Past the Post' (FPTP) electoral system has many structural flaws. But, there is no other option for FPTP in the Indian parliamentary democracy. In this regard, time to time electoral reforms are essential for the healthy democracy, faith of the Indian citizens in this electoral system, free and fair elections. The term 'Electoral Reform' refers to the change in the systems of election process in order to improve on the desirability of the public in the election results (Goyal and Awasthi 2019).

One of the major factors for the electoral reforms is change of voting process, election funding, election campaign, criminalization of politics and growing suspicion on election commission. Therefore, electoral reforms are necessary to functioning of parliamentary democracy in India. In this regard, the election commission, the high courts, the supreme court, the national law commission, parliamentary committees and the Parliament have taken many steps for the electoral reforms. The main focus of this article is to highlight the requirement, issue and challenges for the electoral reforms in India. This article is divided into five parts. First part is introduction. Second part focuses on need of electoral reforms. Third part deal with issues and challenges for the electoral reforms. Fourth part focuses on initiative taken by the election commission, the judiciary and the legislative. Fifth part is conclusion.

\section{Need of Electoral Reforms}

In parliamentary democracy, representation is linked with elections at regular intervals. Elections are only mechanism in which representation, government formation, control on government and change in ruling political parties are conducted. Therefore, elections are essential features of parliamentary democracy. But only elections 
are not criteria to fulfil the aspirations of people. Free and fair elections are necessary for healthy democracy. Democracy" and "free and fair election "are inseparable twins (Baruah 2018, p. 1).

In this regard, electoral reforms have paved the way for free and fair elections. Electoral reforms refer to introduction of best practices in ensuring better responsible parliamentary democracy, removal of structural flaws, clean politics, honest politicians, maintain citizens' trust, true representation and so on. We need electoral reforms, and need them urgently, if we wish to ensure healthy democracy, at least in a workable form if not in its ideal form, survives in the country (Chhokar 2010, p. 3977). Indian constitution's article 324-329 deals with elections and electoral reforms.
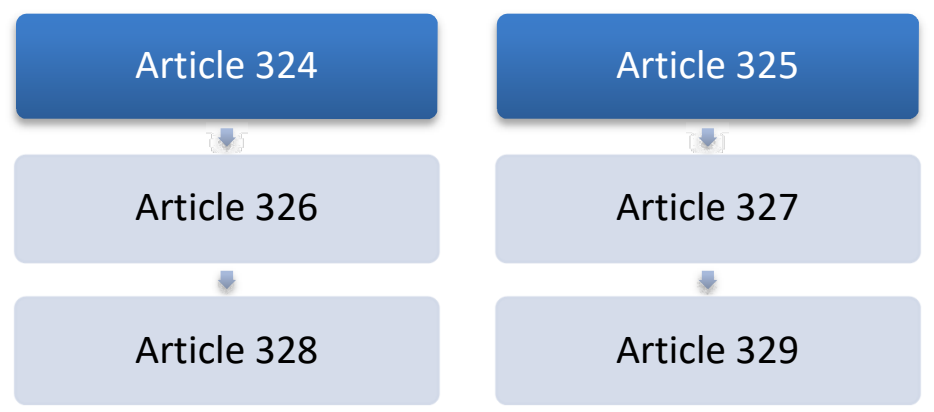

Fig: 1:1: Constitutional Provisions for elections and electoral reforms

Transparency of background of candidates, freeing the election processes from muscle and money power, transparency in election funding, giving right to information to Indian citizens, assured facilitating of vote casting, removal of criminalization of politics, upholding the secrecy of voters, secure free and fair elections, fair registration and recognition of political parties, the solution of delisting of voters, non-partisan role of media, applying the model code of conduct efficiently, rationalising electoral processes are aspects of electoral reforms in India.

The Need for electoral reforms has also been felt mainly due to fulfil the aspirations of young generation, prohibit the criminalization of politics, discourage the muscles and money power, stop the misuse of the government machinery, enhance the trust in the eyes of of citizens, make election commission stronger, make election commission independent and employ the use of technology in electoral process. In 2019, the citizens of India delivered their verdict in electing members of parliament. In the biggest democratic process nearly 613 million voters exercised their franchise. It was the culmination of a prolonged and acrimonious election campaign. In this election issues of EVMs and biasness of election commission have emerged. The role of election commission in 2019 lection is doubtful. The election commission has lost its legitimacy before opposition parties and voters. The election commission was functioning like shareholders of business company. On the other side, EVMs issue has broken the trust of voters. Therefore, it is urgent requirement to settle these issues.

Political finance reform is need of time. Recent disclosures on electoral bonds raise questions. Election funding in India needs to be more transparent. The implementation of electoral bonds scheme raises grave questions. In this regard, allowing the State Bank of India, a government-owned bank, rather than the Reserve Bank of India, to be issuer of electoral bonds raises questions. Therefore, the electoral bonds are opaque in nature.

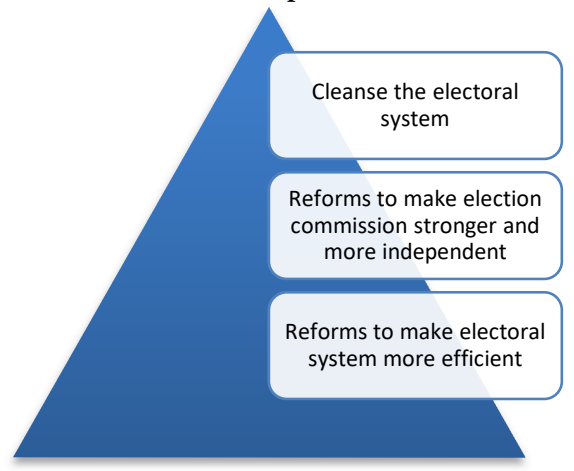

Fig: 1:2: The requirement of electoral reforms in three broad categories

\section{Issues and Challenges for Electoral Reforms}

The Elections are practical form of parliamentary democracy. Elections cover every part of the electoral system. The word election has been used in part of XV of the constitution of India. In India entire electoral process rests on three pillars-Article 326 of the constitution, the representation of the People Act 1950 and the representation of the People Act, 1951. 


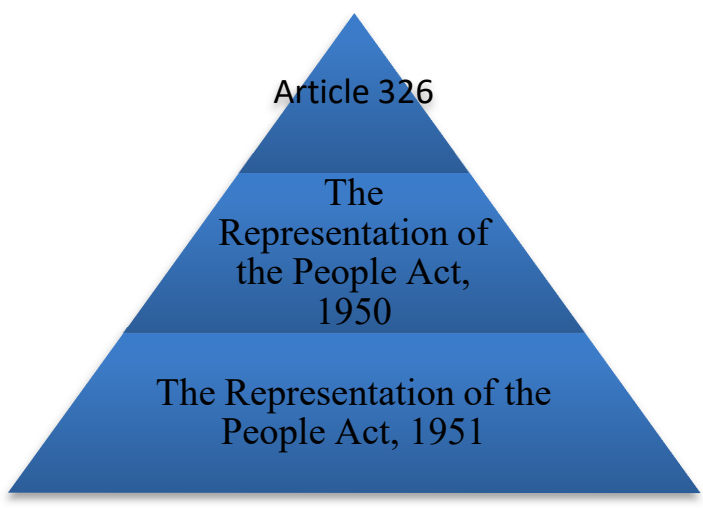

Fig: 1:3: Three pillars of electoral process in India

But the elections are not being held in ideal conditions because of enormous use of money power, muscle power, misuse of corporate funding, misuse of government machinery, biasness of election commissioner and other reasons. Today, India's democracy is facing serious challenges. The absolute disintegration of political values has posed serious threat to Indian democracy. The criminalization of politics is serious threat to healthy functioning of democracy. According to the association of Democratic Reforms nearly half of the $17^{\text {th }}$ Lok Sabha members have criminal charges against them. Of the 543 elected Lok Sabha members 233 have criminal charges.

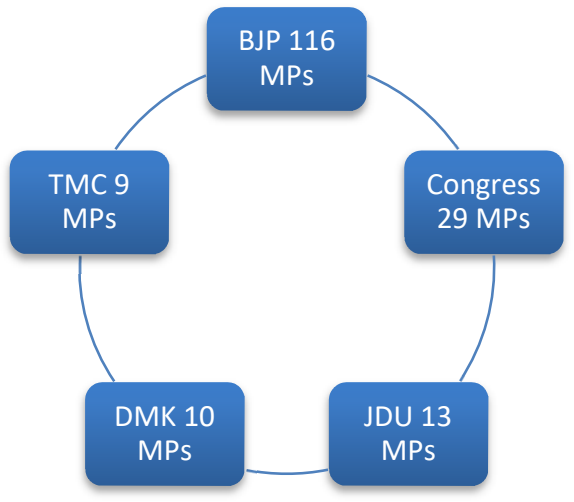

Fig 1: 4: $17^{\text {th }}$ Lok Sabha Members with Criminal Background

(Source: Association of Democratic Reforms)

According to Association of Democratic Reforms, 29 per cent elected members of $17^{\text {th }}$ Lok Sabha have criminal cases of rape, murder, attempt to murder and crime against women. Since 2009, 109 per cent has increased in the number of MPs with serious criminal cases. In 2009 Lok Sabha elections 162 winners had declared criminal cases against themselves. In 2014 Lok Sabha elections 185 winners have declared criminal cases against themselves. The political parties having become a shelter home for criminals. Now, criminal representatives of legislatives are involved in rule making process. This is serious issue before electoral reforms. There is no legislative act to prevent criminal politicians from rule making process. Booth capturing, violence, pre-election intimidation, victimisation is mainly the product of muscle power (Goyal and Awasthi 2019, p. 68).
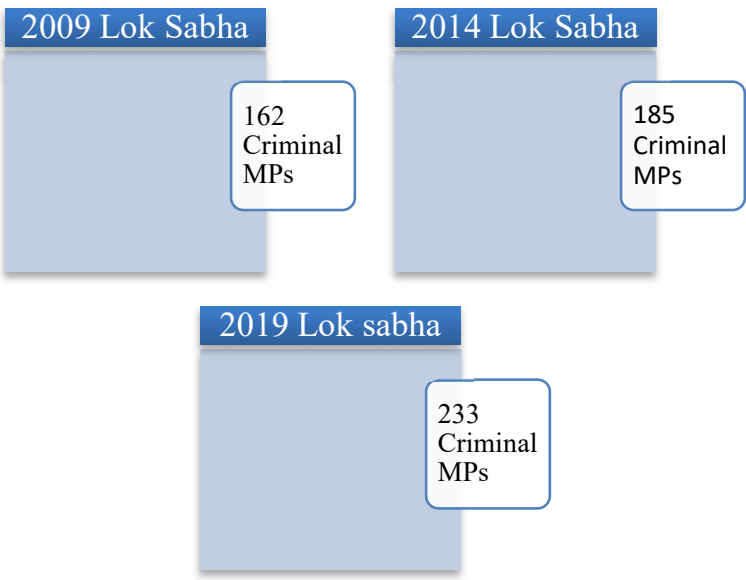

Fig: 1:5: Criminal Members in three Lok Sabha (Source: Association of Democratic Reforms) 
The voters should be aware of the contribution to political parties by various donors in parliamentary democracy. The political funding by the unknown person and corporate houses are serious thereat to parliamentary democracy. Since 2009 big business houses funding to political parties have increased. The big business houses have become effective interest groups which has enormous pressure on government to fulfil its economic aspirations. The Finance Bill 2017 introduced 'Electoral Bonds' scheme as political funding for transparency. The electoral bonds are available in State Bank of India (SBI) for purchase. The scheme allows individuals and domestic companies to purchase theses bonds for political funding.

Buyers of the electoral bonds are required to submit 'Know Your Customer (KYC)' details at the time of buying. But the beneficiary political parties are not required to reveal the identity of donors. Thus, electoral bonds are itself opaque in nature. The government can take advantage from other political parties because electoral bonds are in government owned SBI. But electoral bonds have converted into recycling of black money. The electoral bonds are working as political bribery. It has made corruption official because of absence of disclose of identity of donors. The electoral bonds scheme resulted in money-laundering. Mumbai, Kolkata and New Delhi witnessed the maximum sell of electoral bonds. It means big business houses are major source of political funding.

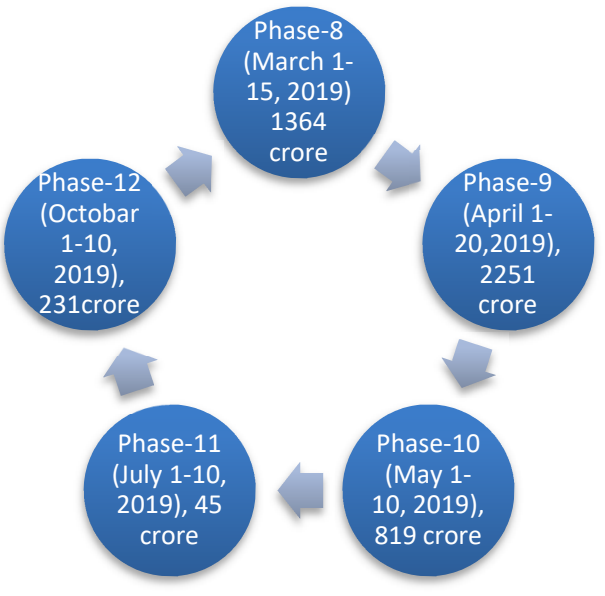

Fig: 1:6: Political Funding by Electoral Bonds During 2019 (Source: Association of Democratic Reforms)

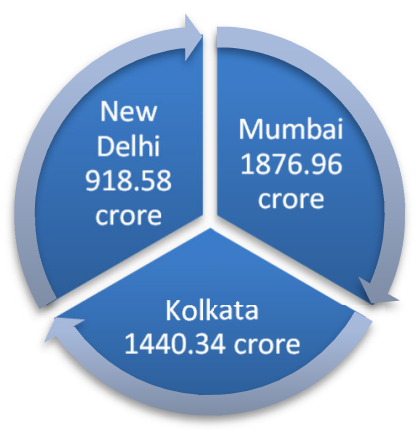

Fig: 1:7: Electoral Bonds Sold, City by City (Source: Association of Democratic Reforms)

Misuse of government machinery is major challenge before electoral reforms. During election government machinery becomes propaganda machinery of the ruling party (Kaur 2016, p. 257). Ruling party or ruling alliance used government machinery for election campaign and surveillance of opposition parties. Misuse of government machinery leads to the abuse of state funding. The politics of communalism, caste and religious fundamentalism poses serious threat to democracy. The politics of communalism and caste have diverted the issue of development. Religious polarization posed a threat to the Indian Political spirit of pluralism. The hate speech against religious community has become new trends of election campaign. The hate speech has emerged as rallying points to gain electoral support. The misuse of official machinery takes different forms, such as issue of advertisements at the cost of government and public exchequer highlighting their achievements, disbursements out of the discretionary funds at the disposal of the ministers, use of government vehicles for canvassing etc (Satish 2017, p. 299)

Paid news is serious issue for electoral reforms. According to the Press Council's report, paid news is "any news or analysis appearing in any media (print \& electronic) for a cash or kind as consideration. The Election commission of India found 120 cases of 'paid news' during $17^{\text {th }}$ Lok Sabha election in 2019. But there is no law to regulate the menace of paid news in India. Paid news is obstacle in free and fair elections since voters influenced by news reports. Paid news publishes as advertisement totally misleading the electors. The paid news involves use of black money and underreporting election expenses.

Opinion polls has emerged as new challenge for free and fair election. Opinion poll confuse the voters. Opinion polls is against the right to freedom of speech and expression granted under Article 19 (1) (a) of the constitution. There should be a prohibition on publication and broadcast of opinion polls during election process. The manipulated opinion polls could impact the voting pattern. Opinion polls often tend to cause a prejudicial effect on the minds of the voters.

In recent elections, the credibility of the Election Commission of India (ECI) has suffered. The ECI has administrative functions for electoral process under Article 324 of the constitution. The Election Commission is the custodian of the secret votes. The role of some election commissioners during elections have affected the functions of the ECI. It has not been able to prevent Prime Minister Narendra Modi from violation of model code of conduct. In this matter only election commissioner Ashok Lavasa dissented with other two ECI commissioners on the issue of violation of model code of conduct by Prime Minister Narendra Modi. It has failed to stop the live 
broadcast of political rallies on TV channels on polling days. The ECI has failed in this issue due to pressure from ruling party. The last six years has shown helpless of the ECI. The ECI has unable to ensure its free and fair work.

The defection is also major issue for electoral reforms. The defection has lowered the legitimacy of democracy. The parliament has taken legislative approach to address the problem of defection. In this regard, the anti defection law was passed in 1985. The anti defection law is contained in the $10^{\text {th }}$ schedule of the constitution. The purpose is to curb political defection by the legislators. The horse trading during the Rajya Sabha election has shown loopholes in this act. Political parties are bypassing the anti-defection law.

\section{Electoral Reforms: An Overview}

Indian parliamentary system stands as model for many emerging democracies around the world. Free and fair elections are essential features of democracy. The heart of India's democratic system witnesses regular elections with the participation of the largest electorate in the world (Election Commission of India Report 2016, p. 1). While we are justifiably proud of our democracy, there are a number of areas which need to be strengthened for us to realise the true potential of a well functioning democracy (Ministry of Law and Justice Report 2010, p. 24). Indian Electoral process is in dire need of significant changes.

Electoral reform means introducing fair electoral systems for conducting fair elections. It also includes recuperation of the existing systems to enhance and increase the efficiency of the same (Saroha 2017, p. 271). The process of electoral reforms is successful only when there is a coordination among the electoral machinery, the political parties, the candidates and electorate at all levels (Ravikiran 2020, p.1) Therefore, the Election Commission of India, numerous government committees and Supreme Court have introduced many electoral reforms to strengthen democracy in India.

The legislative approach for electoral reforms is not satisfactory in India. Only, the Parliament has passed the anti-defection act in 1985. In the recent time, the constitutional provision of anti-defection law has lost its legitimacy. The purpose of anti-defection law is to deter MLAs and MPs from defecting from their political parties. The anti-defection to address the political parties' loyalties of elected representatives has multiple problems. The topic of electoral reforms has been taken by numerous government committees in the recent past:

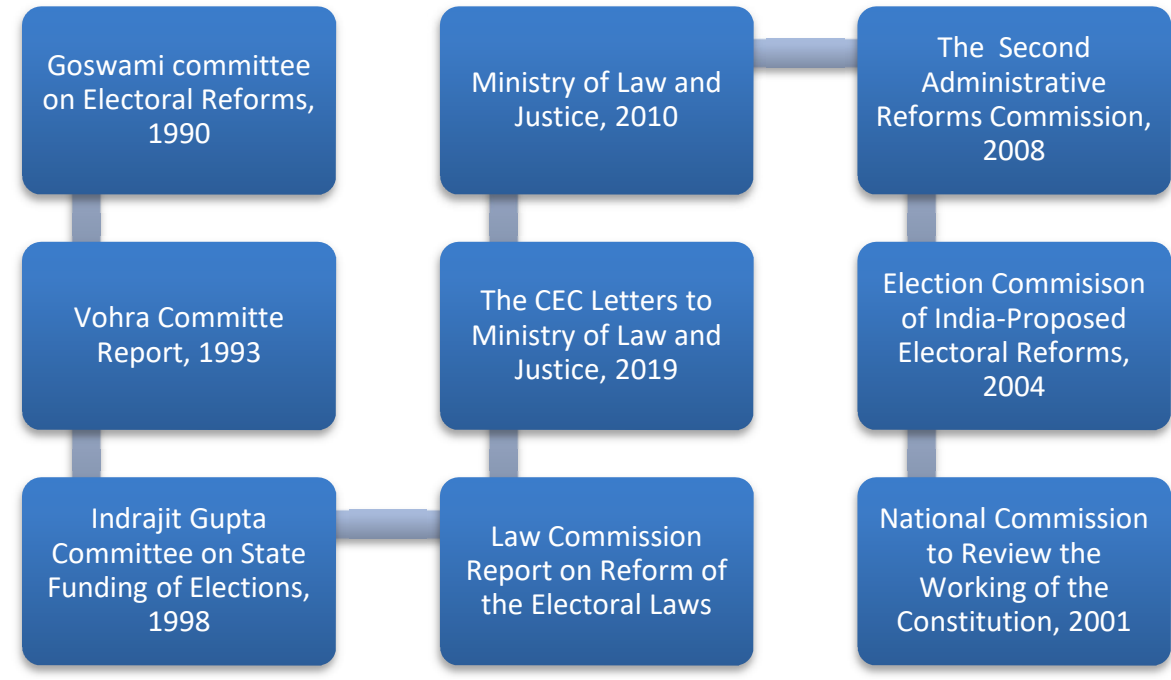

Fig: 1:8: Initiatives for Electoral Reforms

(Source: Ministry of law and Justice, Government of India)

Since 1990s the Election commission of India (ECI) has taken initiatives for electoral reforms. The role of the Election Commission of India in conducting free and fair elections, has become more crucial for the consolidation of India's democracy (Venktesh 2015, p. 85). During 1990s, the Chief Election Commissioner (CEC) T.N. Seshan has been credited for several electoral reforms that end malpractices and brought transparency. The CEC Seshan's reforms by and large change the face of Indian elections.

The ECI has effectively enforced Model Code of Conduct during election process till 2014. But implementation of Model Code of Conduct during elections gradually has been dependent on the will of the CEC.

In this regard, the ECI has introduced voter lists with photo to prevent bogus voting in elections. Further, the ECI has proposed linking Aadhaar with voter identity card in an effort to clean up electoral rolls. The ECI has also proposed making paid news and filling of false affidavit a corrupt practice with punishment of two years imprisonment (The Election Commission of India 2016, p. 1-73). The ECI has asked the Ministry of Law and Justice to make bribery during poll period a cognisable offence. The ECI wants to bring bribery in the category of 'serious' crimes like murder, dowry, death and rape. Presently, conviction is an electoral offence is a ground for disqualification. The ECI has demanded powers of de-register a party on the ground of poll violation rules. 
The criminalisation of Indian political system has been observed by the ECI and the Supreme Court. The government of India had constituted Vohra Committee (1993) to identify the extent of the political-criminal nexus. In 1993, the Vohra Committee appointed by the Government of India had stated in the strong terms that the nexus between crime syndicates and political personalities was strong (Ramesh 2011, p. 1326). In this regard, the Supreme Court has made provision of mandatory of the disclosure of criminal antecedents of candidates and restriction on convicted politicians to contest lection. The Supreme Court has issued an order in 2003 that candidates must file an additional affidavit stating (i) information relating to all pending cases in which cognizance has been taken by a Court, (ii) assets and liabilities, and (iii) educational qualifications (Ministry of Law and Justice 2019).

The financing of elections has become a major issue in the electoral process. The cost of contesting elections has climbed for above the ECI's spending limits. This has resulted in lack of transparency, widespread corruption, and the pervasiveness of so-called 'black money' (Ministry of Law and Justice 2019). The Supreme Court has given order in 2018 that candidates now have to declare source of income with reveal their income. In this judgement the Supreme Court asked the candidates while filling their nomination papers, declare their assets, assets of their spouse, children and other dependents.

The ECI has taken steps to maintain trust of electors on use of EVMs in the elections. In this regard, Voter Verifiable Paper Audit Trail (VVPAT) machines are used during election process to verify that the vote polled by voter goes to the correct candidates. VVPATs are a second line of verification. VVPATs have been used in some elections in a bid to prevent tempering of EVMs. It is essential to improve voter confidence and ensure transparency of voting through VVPATs. During $17^{\text {th }}$ election, the 'C-vigil' app was launched as a step towards greater citizen empowerment. Citizen could geotag pictures and report cases of violation on the portal, with assured action within 100 minutes of reporting.

\section{Conclusion}

The most important feature of a democratic polity is elections at regular intervals. Elections are practical form of parliamentary democracy. The consent of the electors is expressed through the elections in parliamentary democracy. Election process provides legitimacy to the authority of the government. Periodic elections are necessary for maintaining trust of electors. Elections have emerged as an instrument of political awakening. India is the world's largest democracy and has evolved mechanism of free and fair elections. But free and fair elections are not sufficient for democracy. There is urgent requirement of large scale electoral reforms to remove poll related malpractices and to cleanse the system. There are many issues and challenges before electoral reforms in India.

Electoral reforms are necessary for healthy democracy, establishment of responsible government and other purposes. In India, electoral reforms are not a single time effort, but a continuous process. Therefore, there is a continuous attempt by the Election Commission, National Law Commission, the Parliamentary Committees on electoral reforms, legislative acts, high courts, supreme court to reform the electoral system in India. The degree and nature of electoral reforms will require wider debate and political consensus. The ECI and the Supreme Court can be enabler of this electoral reforms. But the functions of the Election Commission should be transparent and independent.

\section{References}

Dash, Siddhartha (2006), "Need for Electoral Reforms", Journal of Odisha Review, Vol. 1, No. 1, pp. 1-14.

Election Commission of India (2016), "Proposed Electoral Reforms 2016", By Chief Election Commissioner Dr. Nasim Zaidi, website: https://eci.gov.in/files/file/9236-proposed-election-reforms/ p. 1-73.

Election Commission of India (2020), “Awaiting Law Ministry Nod on Poll Reforms: Election Commission”, Website: https://eci.gov.in/files/file/395-awaiting-law-ministry-nod-on-poll-reforms-election-commission/

Election Commission of India (2020), "Election Commission of India Held Detailed Discussions with the Legislative Department of Ministry of Law and Justice On Various Issues of Pending Electoral Reforms On $18^{\text {th }}$ February 2020",Website: https://eci.gov.in/gallery/image/1889-election-commission-of-india-helddetailed-discussions-with-the-legislative-department-of-ministry-of-law-and-justice-on-various-issues-ofpending-electoral-reforms-on-18th-february-2020/

Election Commission of India (2020), "Election Commission of India holds a meeting with all the recognised National and State Political Parties at New Delhi on various electoral reforms" Website:https:/eci.gov.in/files/file/5022-election-commission-of-india-holds-a-meeting-with-all-therecognised-national-and-state-political-parties-at-new-delhi-on-various-electoral-reforms/.

Gehlot, S (2019), "India is Overdue for an Electoral Reforms", Journal of Current Science, Vol. 1, No. 1, pp. 112.

H.M, Sanjeev Kumar (2016), Contemporary Indian Politics: Internal Dynamics and External Compulsions, Pinnacle Learning: New Delhi, pp.1-50.

Kaur, Hardeep (2016), "Electoral Reforms in India-Challenges", International Journal of Applied Social Sciences, 
Vol. 3, No. 7, pp. 256-262.

Kumar, B. Venkatesh Kumar (2002), "Critical Issues in Electoral Reforms", The Indian Journal of Political Science, Vol. 63, No.1, pp. 73-88.

Kumar, Ravinder (2019), "Electoral Reforms in India”, Journal of Global Research \& Analysis, Vol. 2, No. 1, pp. 46-51.

Kumar, Sanjay (2002), "Reforming Indian Electoral Process", Economic and Political Weekly, Vol. 37, No. 34, pp. 3489-3491.

Ministry of Law and Justice (2010), "Background Paper on Electoral Reforms", Prepared by the Core Committee on Electoral Reforms, pp.1-34.

Ministry of Law and Justice (2020), "Reports on Electoral Reforms", Website: http://legislative.gov.in/reports-onelectoral-reforms

Pathi, Srinibas (2020), “Does India Really Need Electoral Reforms”, Mizoram University Journal of Humanities and Social Sciences, Vol. 6, No. 1, pp. 1-8.

Ramesh, R. (2011), "Historical Perspectives of the Electoral Reforms in India", Proceedings of the Indian History Congress, Vol. 72, No. 2, pp. 1325-1336.

Saroha, Jai Kumar (2017), “Electoral Reforms in India: Issues and Challenges”, Research Journal of Philosophy and Social Sciences, Vol. 43, No. 1, pp. 270-276.

Sastry, Trilochan (2004), "Electoral Reforms and Citizens' Initiatives”, Economic and Political Weekly, Vol. 39, No. 13, pp. 1391-1397.

Sharma, Doli (2019), "Role of Election Commission in Electoral Reforms", Pramana Research Journal, Vol. 9, No. 12 , pp. $48-54$.

Singh, Bimal Prasad (2013), "Electoral Reforms in India: Issues and Challenges", International Journal of Humanities and Social Science Invention, Vol. 2, No. 3, pp. 1.5.

Singh, Pragya (2013), "Electoral Reforms in India: Comparative Analysis with USA and UK”, Socrates, Vol. 1, No. 1, pp. 1-12. 